\title{
Still 'fire in the (full) belly'? Anti-establishment rhetoric before and after government participation
}

\author{
Authors \\ Andrea Ceron, Università degli Studi di Milano, andrea.ceron@unimi.it \\ Alessandro Gandini, Università degli Studi di Milano, alessandro.gandini@unimi.it \\ Patrizio Lodetti, Università degli Studi di Milano, patrizio.lodetti@ unimi.it
}

\section{To cite this article:}

Andrea Ceron, Alessandro Gandini \& Patrizio Lodetti (2020): Still 'fire in the (full) belly'? Anti-establishment rhetoric before and after government participation, Information, Communication \& Society, DOI: 10.1080/1369118X.2020.1776373

To link to this article: https://doi.org/10.1080/1369118X.2020.1776373

\section{Corresponding Author}

Andrea Ceron, Università degli Studi di Milano, andrea.ceron@unimi.it

Dipartimento di Scienze Sociali e Politiche, Via Passione 13, 20122 Milano - Italy

Phone: +39 02503 21266; E-mail: andrea.ceron@unimi.it

\section{Bio}

Andrea Ceron is Associate Professor in Political Sciences at the University of Milan. His research focuses on party politics and social media analysis.

Alessandro Gandini is Assistant Professor in Sociology of Communication at the University of Milan. His research focuses on digital media and digital methods. Patrizio Lodetti is Post-doc Researcher at the University of Milan. 


\begin{abstract}
Scholars argued that anti-establishment parties use a populist rhetoric that appeals to the worst instincts of people. Indeed, populist politicians are often viewed as charismatic leaders that have fire in their belly. While in the past these parties heavily relied on anti-establishment platforms and communication rhetoric, their increasing electoral success along with the growing duties linked with government membership transform them into more established parties, rather than pure outsiders, and cast doubts on the feasibility of keeping a populist rhetoric. This paper compares rightwing and non-right-wing populism, investigating whether populist leaders change their rhetorical strategy once in office, decreasing the level of negativity and adopting a more forward-looking and inclusive style of communication, with a stronger focus on fulfilling the policy proposal made during the electoral campaign rather than blaming political rivals. For this purpose, we collected a new corpus of political speeches extracted from video messages posted on Facebook by four antiestablishment party leaders in three countries (Austria, Italy and Spain), from 2016 to 2018 , i.e. immediately before and immediately after their access to power. Overall, 30 hours of recorded audio from 215 videos (amounting to around 140 million visualizations) have been analyzed using topic models and well-established semantic psycholinguistic dictionaries. The results highlight slight changes in the rhetoric of populist leaders once in power, mostly for non-right-wing populists, as their language becomes less negative, less assertive and more focused on government duties.
\end{abstract}

Keywords: Populism; Facebook video; text analysis; political language; election campaign 


\section{Still 'fire in the (full) belly'? Anti-establishment rhetoric before and after government participation}

\section{Introduction}

For a long time, the relevance of populism in Europe has been negligible. Populist parties were seen as anti-establishment challengers, small in size, extremist in views, and confined into niche areas of the political space. Sporadically some populists managed to grasp media attention due to their striking electoral performance (often reached behind the shield of a charismatic leader). This happened, for instance, to the Swiss People's Party in Switzerland (particularly after 1995), to the List Pym Fortuyn in the Netherlands (2002) and to the Freedom Party of Austria (FPö), which managed to enter into a government coalition in 1999.

Over time, the relevance of populist parties has markedly increased in several European countries, particularly in the latest years. Nowadays, a number of them is getting more and more electorally successful and several parties managed to offer external support to a ruling cabinet or to get direct access to the government office, either alone or in coalition with other populist or nonpopulist parties.

Out of 33 European countries surveyed, the number of governments supported by populist parties increased from 3 in 2010, when the Party for Freedom in the Netherlands granted external support to a minority center-right government, to 8 in 2015, when in Greece the Coalition of the Radical Left (SYRIZA) formed a populist cabinet jointly with the right-wing Independent Greeks, up to 12 in 2018, when a populist coalition was formed in Italy involving Salvini's League (LN) and the Five Stars Movement (M5S), while in Spain Podemos externally supported the Sanchez I cabinet and in Austria the FPö had just restored the center-right coalition jointly with the Austrian People's Party. ${ }^{1}$

Anti-establishment parties tend to adopt an emotional style of communication based on criticism and negativity and use a populist rhetoric that appeals to the worst instincts of people 
(Engesser et al. 2017). Indeed, populist politicians are often viewed as charismatic leaders that have fire in their belly. While in the past these parties heavily relied on anti-establishment platforms and communication rhetoric, their increasing electoral success along with the growing duties linked with government membership make them more established parties (Krause and Wagner 2019); this makes populists less able to present themselves as pure outsiders of the political system and casts doubts on whether keeping a similar rhetoric would be a feasible strategy in the near future.

Pointing to the chameleonic nature of populism (Mudde and Rovira Kaltwasser 2013), we argue that populist parties strategically change their rhetorical approach. Indeed, we present reasons suggesting that, once in office, populist parties could decrease the level of negativity and adopt a more forward-looking and inclusive style of communication, with a stronger focus on fulfilling the policy proposal made during the electoral campaign rather than blaming political rivals for their negative qualities in terms of character-based valence issues.

To test whether, once in office, anti-establishment leaders change their political language we exploit a new corpus of political speeches pronounced by anti-establishment party leaders. Textual data have been gathered from the audio of video messages posted on Facebook, focusing on those that reached a wider audience. From 2016 to 2018, 4 political leaders in 3 countries have been monitored for two months (before the election and after government formation): Luigi Di Maio (M5S, Italy), Pablo Iglesias (Podemos, Spain), Matteo Salvini (LN, Italy), and Heinz-Christian Strache (FPö, Austria). On the whole, 215 videos (watched almost 140 million of times) have been analyzed, for a total amount of 30 hours of recorded audio.

We investigate our research questions taking advantage of several techniques of text analysis. In particular, we combine well-established psycholinguistic dictionaries (Linguistic Inquiry and Word Count, LIWC) and topic models in order to investigate the sentiment, the emotion (negativity, in particular) connected to the message spread by politicians but also the political content broadcast to assess whether, once in office, anti-establishment leaders start to address other topics compared to those emphasized during the electoral campaign. Following the 
idea that not all populists are equal to each other, we explore the differences between right-wing and non-right-wing populists (Mudde and Rovira Kaltwasser 2013).

The results points to a partial effect of government participation on the rhetoric of antiestablishment leaders, particularly for non-right-wing populists, and on the content of their speeches. The findings have implications for the literature on electoral campaigns, government responsiveness, and for the study of populist rhetoric.

\section{Populist content and style: Theoretical framework}

Populism was a contested concept and the academic literature has long been debating on its definition. A plurality of scholars now seems to agree on a minimal definition of this concept, which identifies populism as a 'thin ideology that believes society to ultimately be separated into two homogenous and antagonistic groups - 'the pure people' versus the 'corrupt elite' - and which argues that politics should be an expression of the general will of the people' (Mudde 2004: 543), so that populist parties tend so self-proclaim themselves as the sole representatives of the common people.

Three key notions of populism are usually identified. The first refers to 'people-centrism', i.e. the glorification of the own people, often with the use of ethnic terms and with an emphasis on the myths of a glorious past (Rydgren 2013); the second appeal concerns 'anti-elitism', i.e. criticizing and condemning the allegedly corrupt elites; the third involves 'popular sovereignty' and the claim for its restoration. The use of such key messages, however, is part of a strategy based on clear communication patterns (Ernst et al. 2019).

Wodak (2015: 3) points out that the populist communication 'combines and integrates form and content' and provides 'a dynamic mix of substance and style' so that it is worth examining both ideological key messages and peculiar stylistic elements (Bracciale and Martella 2017; Stockemer and Barisione 2017). Therefore, for the operationalization of populism, one can rely on the analysis 
of political communication (Bernhard and Kriesi 2019) focusing on two main aspects of it, namely the content (topics and ideas promoted by these parties) as well as the style and the specific discourse patterns through which such contents are expressed.

Scholars shed light on the populist rhetoric emphasizing some peculiar traits that are common to many populist messages. These traits can be summarized into three main areas, i.e. negativity, emotionality and sociability. Let us start from the first one. Negativity sends back to the populists' aptitude to paint society in 'dark'. They ascribe negative traits to the elites, discuss about the dangers faced by the society, condemn negative choices made by their rivals, and emphasize negative societal outcomes blaming the establishment as the sole responsible for such crises. By doing that, the populists also adopt a crisis rhetoric, underpinned by the usage of words with a negative tone that point to immorality, scandals and conditions of emergency (Bracciale and Martella 2017; Engesser et al. 2017).

Focusing on populist voters, scholars found that 'populism is hardly ever considered to be a positive voting choice' (Hooghe and Oser 2015: 27); several studies shown that negative evaluations of democratic institutions and hostile attitudes against the political elite are in fact one of the main reasons to explain the electoral success of populists (Spierings and Zaslove 2017). The literature highlights the affinity between populism and negativism, suggesting that such stylistic element is one of the core strategies used by the populists to spread their key messages. Indeed, a content analysis of social media and talk shows statements across six countries (Ernst et al. 2019) found that negativity represented the main element of a populism-related communication: more than half of all populist messages made use of a negative style (19.9\% out of a $38 \%$ of populist statements).

This can also be linked with negative campaigning, i.e. a strategy based on criticizing the opponents by focusing on the flaws of their policy program or of their character based valence attributes, such as incompetence, disunity, immorality, dishonesty and corruption (Ceron and d'Adda 2016). Opposition parties usually resort more to negative campaigning. As long as populist 
parties are in opposition, we can expect them to exploit negative campaigning, rather than positive campaign, and to communicate their messages using a negatively connoted style. In this regard, studies found that populist parties do tend to engage more in negative campaigning (Nai 2018), unless they are in power (van Kessel and Castelein 2016).

If populists win the elections getting access to the government (or obtaining a full control on it, as in Greece, Hungary or Italy), they become part of the establishment they used to criticize. If so, behaving as in a 'permanent campaign' framework and maintaining a harsh anti-elitist rhetoric to target established parties becomes more and more an unfeasible strategy. Some studies argued that in that case populists could moderate their anti-establishment appeals by toning down their rhetoric (Akkerman 2016; for a review: Krause and Wagner 2019).

The same argument could apply to the adoption of a crisis rhetoric. When painting the world in 'black', by blaming the wrong choices took by the establishment which generated a crisis, populists will not only adopt a negative style. They will also share a backward-looking perspective, that is more oriented on past events, rather than on what has to be done in the near future. Once in office for populist parties it will be harder to only blame the former elite for the mistakes made in the past. Conversely, they ought to employ a rhetoric that is focused more on the future to explain what they will do to rule the country and solve the problems.

To the contrary, other studies suggest that anti-elite criticism did not completely disappear from the discourses of ruling populist parties (Aslanidis and Rovira Kaltwasser 2016; Batory 2016). Populists can in fact look for other (possibly external) enemies, targeting them instead of the national political elite that was previously in power. This reasoning suggests that the rhetoric of negativity might persist. What can change is the target of such negativity. The list of new potential enemies includes the European Union or other supranational and intergovernmental institutions (e.g., the World Trade Organization or the United Nations), foreign countries, multinational corporations, non-governmental organizations, but also foreign capitalists, opulent millionaires, 
small niches of people representing economic and cultural elites, the mass media, or non-elected national democratic institutions that might limit the effectiveness of government.

RQ1: When populists get into office do they adjust their rhetoric style by decreasing negativity and adopting a forward-looking discourse or do they simply change the target of their negativity?

Apart from negativity, emotionality is a second stylistic element deemed crucial in populist communication. The best way to get in touch with the common people is to share emotions and reveal feelings. Beside negative emotions, in fact, populists can also express positive emotions directed to the people or the populist leader himself. Populists can express a positive communication also in patriotic terms to emphasize (and idealize) the qualities of their own country and the myths of the distant past. In addition, within the boundary of emotionality scholars also argue that populists tend to speak with un unflattering assertive tone, avoiding hesitations (Engesser et al. 2017; Ernst et al. 2019). As such, populist actors can resort to a more emotional language (Bracciale and Martella 2017; Engesser et al. 2017; Hameleers et al. 2017) so that the share of emotional words and contents will be overall higher than that of other parties. Content analysis of politicians' statements suggests that emotionality is the second style used in populism-related communication: Ernst and colleagues (2019) classified almost one third of the populist statements in this category $(12.2 \%$ out of $38 \%)$.

Once in office, however, due to the commitments linked with government responsibilities, even populist parties might want to adopt a less emotional language, in favor of a more analytic discourse. In addition, the need for negotiations and compromises (Akkerman 2016), particularly in coalition governments, suggests that populists can adopt a lesser rate of exclusive words and a more inclusive language, reducing their propensity to paint the society in black and white terms (Ernst et al. 2019). However, some positive emotions can still be conveyed to celebrate the successful 
electoral performance and to depict this victory as a revolution that succeeded in dissolving the hated political establishment to install the 'government of change'.

The third stylistic element of populist communication has to do with sociality, and can be partially related to the previous one. Scholars argue that the populists tend to reduce complexity by adopting a colloquial language, using simple words and dialects in order to reach an audience of ordinary citizens (Bracciale and Martella 2017; Engesser et al. 2017). Analogously, to show their friendly nature, populists are prone to use an intimization style, discussing about their personal life in order to be perceived as common citizens easily reachable by the voters (Bracciale and Martella 2017). This element seems less relevant as empirical analyses (Ernst et al. 2019) found a marginal use of sociability compared to other populist-related styles of communication (only $4.8 \%$ of politicians' statements follow this stylistic approach).

RQ2: When populists get into office do they lower the level of emotionality in favor of a more complex and less personal language, adopting fewer excluding words, or do they keep using a sociability style and emphasize the emotions linked with the electoral victory and the political change?

Finally, according to the academic literature, there is a fourth element linked with communication for which we might foresee a change when comparing populists before and after the electoral success. In fact, when populist parties are in opposition, beside an anti-elite rhetoric they also focus their strategy on offering a clear set of policy promises during election campaigns (Akkerman 2016; Krause and Wagner 2019). Being in the opposition, free from any government responsibility, populists might offer unfeasible policy claims and make promises that they would not be able to fulfil later. Populist parties are often deemed unable to deliver once in office (Heinisch 2003; Kitschelt 2007). To cope with this, when populist parties seize power, they should make an effort to present themselves as credible political agents that can successfully implement policies and fulfil promises, being responsive toward the demands of voters. 
By doing that, the populists can detach themselves from the former political elite, which was accused to lack responsiveness and to ignore the voters' wills. Additionally, this strategy is crucial to preserve their electoral support and to avoid a valence loss, linked with the deterioration of their image of credible agents of policy change (Krause and Wagner 2019). Indeed, for such parties that are often considered as policy-seeker, succeeding in policy implementation and fulfilling election pledges becomes crucial to enhance the likelihood of their survival (Akkerman and de Lange 2012). Accordingly, after joining the cabinet, one can expect a stronger emphasis of populists' communication on the core issues and the main policy pledges discussed during the electoral campaign. If the reasoning leading to our first research question suggested that we should observe less negativity (including less negative campaigning) along with a forward-looking lexicon, this latter discussion points in a similar direction, indicating that we can expect a stronger emphasis on the core policies that will have to be (profitably) addressed by the new populist government.

RQ3: When populists get into office do they increase the share of policy-related statements to prove their ability to fulfil electoral pledges?

Noticeably, while populism is a wide phenomenon that includes both right-wing and left-wing variants, not all populist parties are equal to each other and the literature distinguishes between right-wing and left-wing populists. Both retain anti-establishment views, being similar on the socalled anti-elitist (vertical) dimension of populism; however, concerning the nativist (horizontal) dimension of it, right-wing populists are deemed exclusionary in nature (Heiss and Matthes 2020) while left-wing populists follow a more inclusionary logic (Mudde and Rovira Kaltwasser 2013).

As discussed above, relying on anti-elitist populism can become more unfeasible once in office (since the elite was defeated); conversely, exclusionary populist arguments related to the nativist/patriotic dimension of populism can still be used, and right-wing populists can foster ingroup/out-group dynamics claiming that they are defending the interests of the in-group against several out-groups (Heiss and Matthes 2020). Furthermore, the exclusionary nature of right-wing 
populists suggests that they are less adaptable and less prone to meet the need for negotiations and compromises in coalition governments (Akkerman 2016).

Therefore, one can argue that right-wing populists are less prone to get fully embedded into institutions: they try to partially preserve their purity and keep one foot in and one foot out of institutions, to avoid becoming part of the system, especially 'in terms of the linguistic register adopted' by their leaders (Albertazzi and McDonnell 2005: 959).

As such, throughout the paper we will answer our broad research questions on a variety of outcomes and from multiple facets, paying attention also to the potential differences between rightwing and non-right-wing populists.

\section{Case selection and data collection}

Moving beyond the analysis of textual Twitter data, in the present paper we will investigate the communication of populist leaders using videos posted on Facebook.

The choice to focus on videos fits well with the study of populism. Compared to a written text, in a video a charismatic leader has the opportunity to establish a direct link with the audience showing his face and a slice of his real life, and using his voice and visual nonverbal cues to strengthen the efficacy of the contents and words expressed in the speech. The content broadcast on video is also more usable, compared to a written text, as it requires a lower effort from the consumer, who can just listen (even passively) instead of reading (actively). Due to its efficacy and to its ability to become viral, reaching a wider audience, this source of data will be very relevant in the upcoming future. Indeed, the consumption of branded video content is rapidly increasing: on Facebook it grew by $258 \%$ from 2016 to $2017 .^{2}$

In turn, focusing on Facebook, instead of other social media (e.g., Twitter), seems appropriate and coherent with our research design. For populist purposes, Facebook has several advantages compared to Twitter (Ernst et al. 2019: 5): it offers more reciprocal message exchanges 
and 'it has higher levels of proximity and the connection between Facebook users is generally more intensive, personal, and intimate'. Furthermore, due to the socio-demographic features of Twitter users (such as education, socioeconomic status, or political interest), political actors consider Twitter less suitable for spreading populism (Jacobs and Spierings 2019) compared to Facebook, which is a platform that allows also ordinary citizens to interact with politicians (Kalsnes et al. 2017). Indeed, populist citizens tend to use Facebook as a source of political information (Schulz 2018), and empirical content analyses of political messages show that political actors prefer Facebook (over Twitter or televised debates) as an outlet for their populist-related communication (Ernst et al. 2019). All these reasons indicate that Facebook is more suitable for populist communication. Last but not least, Facebook remains the most widely used social media in all the countries considered in the analysis; its penetration and market share are strikingly high so that an audience of millions of voters is potentially exposed to the video content broadcast there by populist leaders. In the period considered, the potential audience on Facebook amounted to almost 22 million of users in Italy ( $36 \%$ of the population), ${ }^{3}$ more than 19 million in Spain ( $41 \%$ of the population $)^{4}$, and around 4 million in Austria (46\% of the population).$^{5}$

Our aim is to investigate whether and to what extent populist parties have changed their rhetorical strategies after seizing power, exploring any potential difference between right-wing and non-right-wing populists. To do that, we focus on the communication of populist parties that have recently shifted from the opposition to a ruling position. Given that the data collection is based on video content spread on Facebook, we restrict the time frame of our analysis to the latest years in which videos started to play a prominent role in social media communication, i.e. starting after 2016. For this reason, we do not consider SYRIZA in Greece (2015), the Danish People's Party (which supported the center-right cabinet in 2015), or the Slovak National Party that joined the cabinet in early 2016. The volume of video data concerning these three parties would be too low to perform any analysis. Consequently, we focus on four populist parties that switched their status, from government to opposition, later than 2016: the Freedom Party, in Austria, which got involved 
in the coalition government in December 2017, soon after the general election held in October; the League and the M5S, which formed a coalition in June 2018 (after the Italian election held in March) and the Spanish Podemos, which contributed to the dismissal of the center-right cabinet led by Mariano Rajoy voting a motion of no-confidence, jointly with the Spanish Socialist Workers' Party (PSOE) and with regionalist parties in June 2018. This motion resulted in the downfall of Rajoy (who was in office after the 2016 election) and in the PSOE leader Pedro Sánchez becoming new Prime Minister of Spain. According to the Spanish Constitution, Sánchez was automatically deemed to have the confidence of the legislature as the motion of no-confidence reached a majority, therefore, Podemos provided an external support to the socialist cabinet led by Sánchez.

While scholars have long neglected the analysis of left-wing populism, recent studies have started to investigate populism distinguishing between left and right (Bernhard and Kriesi 2019; Ernst et al. 2017, 2019; Krause and Wagner 2019; Rooduijn and Akkerman 2017; Schmuck and Hameleers 2019). Accordingly, in the present paper we investigate two right-wing populist parties, i.e. the LN and the FPö, and two non-right-wing populist parties, i.e. the left-wing Podemos and the Italian M5S. Notably, scholars are unsure about the political location of the M5S. Its leadership defines itself beyond left and right (Hooghe and Oser 2015; Mosca 2014). Some studies point to its eclectic or polyvalent nature (Mosca and Tronconi 2019; Pirro 2018), while others consider it as a moderate (Ernst et al. 2019) left-of-centre party (Ernst et al. 2017), or as a radical left party (Bernhard and Kriesi 2019; Ceron 2017a; Conti and Memoli 2015). Overall, the M5S seems to combine left-of-centre positions on economy and welfare with vague, elusive and mixed (sometimes progressive, sometimes conservative) views on socio-cultural issues (Ceron 2017b; Mosca and Tronconi 2019). Nevertheless, 2018 data based on manual coding of its party manifesto, ${ }^{6}$ or of M5S parliamentary speeches during the Conte I investiture debate, ${ }^{7}$ suggest that this party is overall leaning more toward the left than toward the right. These data refer to documents collected immediately before (manifesto) and immediately after (investiture debate) 
M5S access to power, therefore they are suitable, being temporally close to the period of our analysis. Accordingly, we will consider the M5S as a non-right-wing populist party.

From this perspective, our sample is balanced. The literature on digital politics has often focused on communication patterns during electoral campaigns, while non-election periods have been investigated less (with some exceptions: Ceron 2017b; Ernst et al. 2019; Schmuck and Hameleers 2019). Conversely, in the present study we will compare the communication during the electoral campaign (focusing on data concerning the last month before the election), with what happens in times of 'ordinary politics' (Bernhard et al. 2015), i.e. one month after the new cabinet has been installed. Per each party in each country we analyze two months of data, focusing on the official account of the party leader, which can be the most suitable to investigate populism in light of the growing personalization of politics. Many scholars suggest that right-wing populist communication appears centered on the person of the leader (e.g., Krämer 2017); fewer studies address non-right-wing populists (Bracciale and Martella 2017; Ernst et al. 2017), but leaders are deemed important even in these parties: typically, the leaders of Podemos and the M5S personify the party, pushing scholars to discuss about their 'hyperleadership' (Gerbaudo 2019).

Accordingly, the following political leaders have been considered: Luigi Di Maio (M5S, Italy), Pablo Iglesias (Podemos, Spain), Matteo Salvini (LN, Italy), and Heinz-Christian Strache (FPö, Austria). Interestingly, while some parties are older than others and already had experience in office during their life (LN and FPö), this is not true for their political leaders. Indeed, none of them was in office before, nor was leading the party during prior coalition government experiences.

Following these criteria, using a custom-built, ad hoc script, we downloaded 354 videos. To enhance the comparability of the documents, we excluded videos falling in the 25 th percentile in terms of visualization (few visualization, i.e. less interesting content accessed by few users) and falling above the 75th percentile in terms of length (very long videos, which might contain multiple breaks or off topic contents). We manually checked the content to keep only videos in which the leader was directly speaking or spreading the party line; off topic videos were excluded (e.g., videos 
without audio or with a very bad audio, TV reports unrelated to the leader or the party, videos not related to the party leader but to other persons). As a result, 215 videos have been analyzed (this is our unit of analysis): 126 in the last month of election campaign and 89 in the first month after government formation, with an overall balance between right-wing (118) and non-right-wing (97) videos (see Table A1 in the Online Appendix for details).

The total length amounts to 1748 minutes of audio, i.e. almost 30 hours videotaped (with an average of 7.84 minutes per video) and the content has been cumulatively watched $138,300,000$ times (average number of visualizations: 620,277). The audio has been converted into text using the Google Speech API and manually cleaned when necessary, producing a dataset that contains overall 158,623 words, though the length is higher for Salvini and especially for Di Maio.

Facebook videos do not only report original content, thought to be addressed to the Facebook audience. To the contrary, populist leaders broadcast on Facebook contents form a variety of sources that includes interviews in news programs, declaration released during televised talk shows, press releases, speeches delivered at political rallies, and professional advertisements or selfproduced video messages in the form of video-selfies (that were later broadcast also on TV by news programs).

From a qualitative inspection, we notice that the content of Facebook's video seems perfectly representative of the communication style of these populist leaders. For instance, we find videos introducing the viral prize contest 'Vinci Salvini' ('you win Salvini'), a gamification strategy for mobilization and personal data collection purposes, along with selected declarations released on TV or Facebook Live videos recorded directly from the minister's desk or while driving between one electoral campaign rally and the following one.

We proceed with the empirical analysis focusing on the topics, first, using automated topic models to perform an exploratory analysis, and then on the linguistic style using the software LIWC, a well-established psycholinguistic tool that implements semantic analysis through predefined dictionaries. 


\section{Analysis and results}

\section{Topic models analysis}

For the topic model analysis, we revert to an unsupervised non-probabilistic algorithm, the Nonnegative Matrix Factorization, which has some advantages compared to other traditional topic model techniques (see the Online Appendix for references and methodological details). We kept constant the number of topics (5) set ex-ante for all the politicians. We reduced the sparsity removing rare words and selecting only words that appeared more than once in each text, though the substantive results are similar when removing this filter.

Two main patterns seem to emerge from this analysis (see Section 2 of the Online Appendix for extensive details and results). First, we notice a widespread use of valence issues and attacks to rival politicians before the election, while after government formation their new institutional roles bring populists to focus more on policies and government duties. Before the election Di Maio referred to valence issues (corruption, competence and costs of politics) in 4 topics out of 5, while later he spent more effort (3 topics) discussing social policy and economic development ('sviluppo economico'); Iglesias shifted from valence issues (2 topics) to government duties and concrete policies in the fields of devolution, immigration and welfare (4 topics overall); the same pattern applies to Strache (3 valence related topics before the elections, 4 topics about social policy and government duties later). Salvini too devoted more attention to immigration policy once in office (this occurs in 3 topics).

In detail, before the election, several topics concerning the League and the M5S (but also Podemos and the FPö) contain attacks against the leader of the incumbent party ('Renzi' or 'Rajoy'), or refer to the need to face existing 'problems' ('probleme'), in line with a crisis rhetoric, and include mentions to 'corruption' ('corruzione') and to rival politicians ('De Luca') involved in 
corruption scandals. Conversely, after government formation we notice references to respecting 'campaign commitments' ('wahlversprechen'), for instance in the videos of Strache. Similarly, Di Maio discusses about the implementation of public policies in line with the declarations released during the campaign (e.g., the so called 'reddito di cittadinanza': minimum citizenship income); Strache, makes reference to the 'future' ('zukunft') and to social policies for the families ('familienbeihilfe'). Iglesias points to new 'proposition' ('proposición') to be put on the 'agenda', including public services ('servicios públicos') and immigration policy ('puerto'). In turn, Salvini widely focused on immigration policy (boats, 'navi'; borders, 'confini'; immigrants, 'immigrati'; 'Tunisia'), but he also refers to the European Union ('europa'), which can potentially become a new enemy to be attacked using a populist rhetoric.

Indeed, the topic models reveal a second pattern that points to some differences between right-wing and non-right-wing populism. We notice that after government formation the two rightwing leaders still devote attention to very peculiar topics linked with a populist rhetoric, such as patriotism and paternalism. This seems an attempt to preserve a more distinct populist language even once in office. Specifically, Strache makes reference to the issue of traditions (Topic 3, Table A9, Online Appendix) and Salvini adopts a language based on patriotism (Topic 3, Table A5, Online Appendix) and paternalism (Topic 1, Table A5, Online Appendix). This preliminary evidence will be further investigated with a statistical analysis of semantic occurrences.

\section{Semantic analysis}

For the semantic analysis we employ LIWC, i.e. a text analysis program that counts words belonging to psychologically meaningful categories; remarkably, 'empirical results using LIWC demonstrate its ability to detect meaning in a wide variety of experimental settings, including to show attentional focus, emotionality, social relationships, thinking styles, and individual differences' (Tausczik and Pennebaker 2010: 24). 
We revert to 2001 and 2007 dictionaries in Italian, German and Spanish. LIWC is particularly suitable for our purpose as it allows to investigate the style of communication of populist leaders by looking at their words usage and by comparing words falling into alternative categories that can be directly linked with our research questions.

Accordingly, to answer RQ1 and RQ2, we created 8 dependent variables (Positive Tone, Forward Looking, Total Emotions, Inclusive/Exclusive, I/We, Complex Words, Personal, Social) that provide a picture of the three stylistic facets of populist rhetoric described above. All these variables theoretically range from 0 to 100 (see Table A10 and A11 in the Online Appendix). ${ }^{8}$ We analysed each variable through a linear regression with random effects to account for the nested structure of the data (we have repeated observations, i.e. videos, within politicians). ${ }^{9}$

Our main independent variable is a dummy equal to 1 when the video is recorded after government formation (and 0 otherwise). To investigate similarities and differences between populists, we interact this variable with a dummy equal to 1 for right-wing populists (and 0 otherwise). Figure 1 displays the results on all the 8 dependent variables; we report the change in the outcome when a video is published after government formation for all populist leaders (left panel) or separately for right-wing and non-right-wing populist leaders (right panel). The latter representation also allows to detect if the effects hold true for only one of the two groups (Brambor et al. 2006). ${ }^{10}$

\section{[FIGURE 1 AROUND HERE]}

Overall, we notice an impact only on a few outcomes. We observe a stronger focus on the future rather than on the past and the present $(+2.64)$, a more complex language $(+3.01),{ }^{11}$ which partially runs against the populist stylistic element of sociability (in terms of colloquialism), and an evolution toward a less assertive language, which employs relatively more words denoting inclusion than exclusion (+9.35). Conversely, we do not see differences in the tone, the share of emotional 
words or words related to social processes (references to friends, babies and human beings) and personal concerns (both linked with the logic of sociability and intimization: Ernst et al. 2019).

Interestingly, when running separate analyses to distinguish right-wing populists from nonright-wing ones, we notice some additional changes and generally the findings tend to hold true more for the latter than for the former. Once in office, non-right-wing populists tend to use a more positive tone $(+16.04)$; their language gets more complex $(+2.60)$ and less assertive, with a lower emphasis on the first-person singular rather than plural ('we' instead of 'I'; -14.79) and more words denoting inclusion rather than exclusion (+20.80). Conversely, when considering right-wing populists alone, we only find a more complex $(+3.16)$ and forward-looking $(+5.00)$ language after government formation, while no additional change is detected with respect to the other stylistic elements considered.

\section{Discussion}

Our results point to some slight changes in the rhetoric of populist leaders once in power, particularly for non-right-wing populist leaders. The language becomes relatively less negative, more future oriented, and less assertive (more inclusive and less personalized). Despite this, some elements, peculiar of populist communication, are still in place, including a persistent intimization and emotional words are still used, arguably to express satisfaction for the success of the 'populist revolution' and outlining positive expectations in terms of policy change.

This latter finding is also reflected in the topic model analysis, which showed a stronger emphasis on the concept of change, as well as on the actual policy proposals presented during the electoral campaign, at the expense of reduced emphasis on valence attributes and on antiestablishment and anti-elite discourse. This latter strategy remains only partially present, becoming addressed now to other potential enemies such as the European Unions and the multinational corporations instead of the former ruling elite. 
Overall, the evidence of a partial adaptation to their new roles is coherent with the idea that anti-establishment leaders might feel to have a 'full belly': the satisfaction due to government membership can alter their communication strategies reducing the recourse to harsh criticism.

While recent studies show that both populists and non-populists parties are more likely to adopt populist communication before the election than afterward (Schmuck and Hameleers 2019), our results hold true mainly for non-right-wing populist leaders. This can imply that, at least in the very short term, right-wing populists tend to adopt a 'one foot in, one foot out strategy' (Albertazzi and McDonnell 2005); they adapt less to their new governmental role and keep a rather populist style that is more in line with election campaign dynamics. Remarkably, this finding represents a very strong evidence against the idea of the moderation of right-wing populists once in office.

To the contrary, non-right-wing populists do modify their language and seem more ready to get institutionalized passing from harsh criticism to more constructive viewpoints. These findings seem to align with the constructive behavior showed by Podemos in Spain and the M5S in Italy, which repeatedly proved their willingness to enter into office; conversely, both the League and the FPö have suddenly rejected their government posts (although for different reasons).

On the one hand, after the successful performance of the League in the 2019 European elections, Salvini called for snap elections showing his propensity to exploit his consensus among voters instead of promoting the stability of the Conte I cabinet; ${ }^{12}$ similarly, after a political scandal involving Strache, the FPö opted for a mass resignation and withdrew its ministers from the Kurz I cabinet, leading to its termination. ${ }^{13}$

On the other hand, in Italy the M5S tried to bargain either with the center-left Democratic Party or the right-wing League immediately after the 2018 general election to end political instability and form a new cabinet; after Salvini's request for early elections, in the summer of 2019, the M5S moved from an alliance with the League to a new coalition government (Conte II) formed jointly with the Democratic Party and the left-wing party Free and Equal to preserve its cabinet membership. ${ }^{14}$ Analogously, in Spain Podemos has repeatedly invited the socialist party to 
form a formal coalition government that includes both parties, as a sign of its willingness to get into office in a new Sánchez II cabinet (which was finally formed in January 2020). ${ }^{15}$

Beside the limitations of the present study (such as the selection of populist parties only), we should also consider two possible alternative explanations that can apply to our findings. First, the two right-wing populists are junior parties in the government coalition and might need to differentiate themselves from their partner, while the M5S was the largest party in parliament and Podemos was a supporting partner with an incentive to show allegiance to the coalition and prove its reliability (Van Kessel and Castelein 2016). This can be true, though in the Italian case the League immediately closed the gap with the M5S in the voting intention polls (already in June 2018) and was more than just a junior partner (Marangoni and Verzichelli 2019): Salvini led its own agenda and was deemed 'the most influential leader in the Conte government' (Fabbrini and Zgaga 2019: 290); this could have fostered the incentive to adjust the language accordingly (something that we did not observe).

Secondly, both the LN and the FPö had already been in government before. From their previous experience they could have learnt the benefit of keeping a sharp profile. While this is reasonable, we must consider that our paper focuses on party leaders and on their personal communication style; notably, none of them was directly in office before, nor was the party leader during prior coalition government experiences. ${ }^{16}$

Nevertheless, future research could disentangle these concerns, investigating more in depth the differences between right-wing and non-right-wing populists net of any potential confounding factor that we cannot account for in this study. Unfortunately, the cabinets formed with the contribution of these four populist parties lasted only few months; accordingly, future research could possibly investigate changes in the long run. Future studies can also analyze the communication patterns of populists from a qualitative point of view: taking advantage of the increasing relevance of online videos, scholars can grasp whether, beside language, other elements of non-verbal communication change when anti-establishment parties get into office. 


\section{References}

Akkerman, T. (2016). Conclusions. In: T. Akkerman, S.L. de Lange \& M. Rooduij (Eds.), Radical Right-Wing Populist Parties. Into the Mainstream? (pp. 268-282). London; New York: Routledge. Akkerman, T., \& de Lange, S.L. (2012). Radical right parties in office: incumbency records and the electoral cost of governing. Government and Opposition 47(4), 574-596.

Albertazzi, D., \& McDonnell, D. (2005). The Lega Nord in the second Berlusconi government: In a league of its own. West European Politics 28(5), 952-972.

Aslanidis, P., \& Rovira Kaltwasser, C. (2016). Dealing with populists in government: the SYRIZAANEL coalition in Greece. Democratization 23(6), 1077-1091.

Batory, A. (2016) Populists in government? Hungary’s 'system of national cooperation'. Democratization 23(2), 283-303.

Bernhard, L., \& Kriesi, H. (2019). Populism in election times: a comparative analysis of 11 countries in Western Europe. West European Politics, DOI: 10.1080/01402382.2019.1596694 Bracciale, R., \& Martella, A. (2017). Define the populist political communication style: The case of Italian political leaders on Twitter. Information, Communication \& Society, 20(9), 1310-1329. Brambor, T., Clark, W.R., \& Golder, M. (2006). Understanding Interaction Models: Improving Empirical Analyses. Political Analysis, 14(1), 63-82.

Ceron, A. (2017a). Intra-party politics in 140 characters. Party Politics, 23(1), 7-17.

Ceron, A. (2017b). Social Media and Political Accountability: Bridging the Gap between Citizens and Politicians. Cham: Palgrave Macmillan.

Ceron, A., \& d'Adda, G. (2016). E-campaigning on Twitter: The effectiveness of distributive promises and negative campaign in the 2013 Italian election. New Media \& Society, 18(9), 19351955.

Conti, N. \& Memoli, V. (2015) The Emergence of a New Party in the Italian Party System: Rise and Fortunes of the Five Star Movement. West European Politics 38(3), 516-534. 
Engesser, S., Fawzi, N., \& Larsson, A. O. (2017). Populist online communication: Introduction to the special issue. Information, Communication \& Society 20, 1279-1292.

Ernst, N., Engesser, S., Büchel, F., Blassnig, S., \& Esser, F. (2017). Extreme Parties and Populism: An Analysis of Facebook and Twitter Across Six Countries. Information, Communication \& Society 20(9), 1347-64.

Ernst, N., Blassnig, S., Engesser, S., Büchel, F., \& Esser, F. (2019). Populists Prefer Social Media Over Talk Shows: An Analysis of Populist Messages and Stylistic Elements Across Six Countries. Social Media + Society, DOI: https://doi.org/10.1177/2056305118823358

Fabbrini, S. \& Zgaga, T. (2019). Italy and the European Union: the discontinuity of the Conte government. Contemporary Italian Politics 11(3), 280-293.

Gerbaudo, P. (2019). The digital party: Political organisation and online democracy. London: Pluto Press.

Hameleers, M., Bos, L., \& de Vreese, C. (2017). "They did it": The effects of emotionalized blame attribution in populist communication. Communication Research, 44, 870-900.

Heinisch, R. (2003). Success in opposition - failure in government: explaining the performance of right-wing populist parties in public office. West European Politics 26(3), 91-130.

Heiss, R., \& Matthes, J. (2020). Stuck in a Nativist Spiral: Content, Selection, and Effects of RightWing Populists' Communication on Facebook. Political Communication 37(3), 303-328

Hooghe, M., \& Oser, J. (2015). The electoral success of the Movimento 5 Stelle: An example of a left populist vote? Österreichische Zeitschrift Für Politikwissenschaft 44(4), 25-36.

Jacobs, K., \& Spierings, N. (2019). A populist paradise? Examining populists' Twitter adoption and use. Information, Communication \& Society 22(12), 1681-1696.

Kalsnes, B., Larsson, A. O., \& Enli, G. S. (2017). The social media logic of political interaction: Exploring citizens' and politicians' relationship on Facebook and Twitter. First Monday, 22(2). Kitschelt, H. (2007). Growth and persistence of the radical right in postindustrial democracies: advances and challenges in comparative research. West European Politics 30(5), 1176-1206. 
Krämer, B. (2017) Populist online practices: the function of the Internet in right-wing populism. Information, Communication \& Society 20(9), 1293-1309.

Krause, W., \& Wagner, A. (2019). Becoming part of the gang? Established and nonestablished populist parties and the role of external efficacy. Party Politics, DOI:

https://doi.org/10.1177/1354068819839210.

Kriesi, H. (2014) The populist challenge. West European Politics 37(2): 361-378.

Marangoni, F. \& Verzichelli, L. (2019). Goat-stag, chimera or chameleon? The formation and first semester of the Conte government. Contemporary Italian Politics 11(3), 263-279.

Mosca, L. (2014). The Five Star Movement: Exception or Vanguard in Europe? The International Spectator 49(1), 36-52.

Mosca, L., \& Tronconi, F. (2019). Beyond left and right: the eclectic populism of the Five Star Movement. West European Politics 42(6), 1258-1283.

Mudde, C., \& Rovira Kaltwasser, C. (2013). Exclusionary vs. inclusionary populism: comparing contemporary Europe and Latin America. Government and Opposition 48(2), 147-174.

Mudde, C. (2004) The populist zeitgeist. Government and Opposition 39(4), 542-563.

Nai, A. (2018) Fear and loathing in populist campaigns? Comparing the communication style of populists and non-populists in elections worldwide. Journal of Political Marketing, 1-32, DOI: 10.1080/15377857.2018.1491439.

Pirro, A. (2018). The polyvalent populism of the 5 Star Movement. Journal of Contemporary European Studies 26(4), 443-458.

Rooduijn, M. \& Akkerman, T. (2017). Flank attacks: populism and left-right radicalism in Western Europe. Party Politics 23(3), 193-204.

Rydgren, J. (2017). Radical right-wing parties in Europe. Journal of Language and Politics, 16, $485-496$. 
Schmuck, D., \& Hameleers, M. (2019). Closer to the people: A comparative content analysis of populist communication on social networking sites in pre- and post-Election periods. Information, Communication \& Society, 1-18.

Schulz, A. (2018). Where populist citizens get the news: An investigation of news audience polarization along populist attitudes in 11 countries. Communication Monographs, 1-16.

Spierings, N., \& Zaslove, A. (2017). Gender, populist attitudes, and voting: explaining the gender gap in voting for populist radical right and populist radical left parties. West European Politics 40(4), 1-27.

Stockemer, D., \& Barisione, M. (2017). The "new" discourse of the Front National under Marine Le Pen: A slight change with a big impact. European Journal of Communication, 32, 100-115. Tausczik Y.R., \& Pennebaker, Y.W. (2010). The Psychological Meaning of Words: LIWC and Computerized Text Analysis Methods. Journal of Language and Social Psychology 29(1), 24-54. Van Kessel, S. \& Castelein, R. (2016) Shifting the blame. Populist politicians' use of Twitter as a tool of opposition. Journal of Contemporary European Research 12(2), 594-614.

Wodak, R. (2015). The politics of fear: What right-wing populist discourses mean. London, England: SAGE. 


\section{Figure}

Figure 1 - Change in populists' language after government formation (with 95\% confidence interval).

Changes in populists' language after government formation

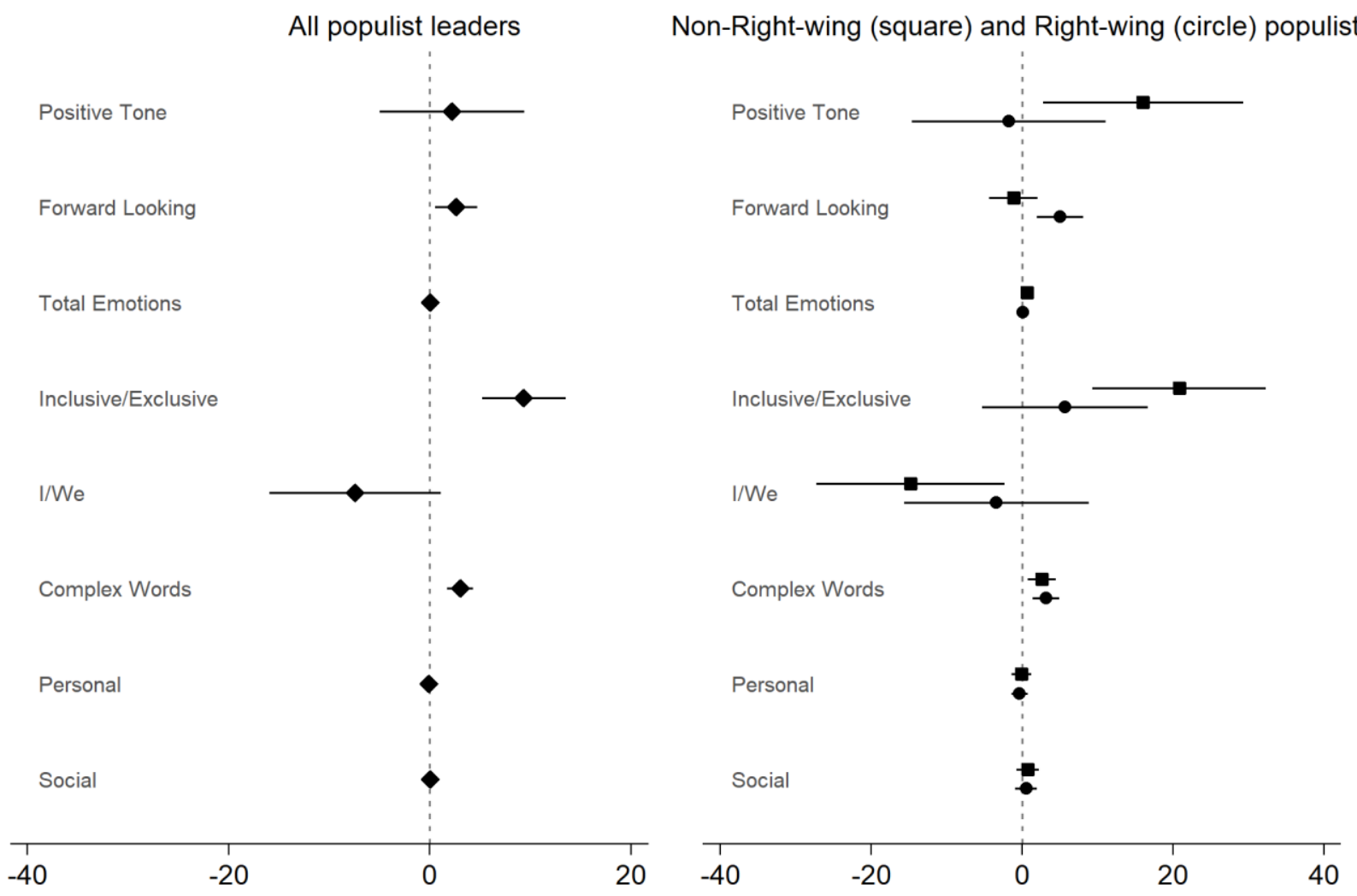


${ }^{1}$ Timbro Authoritarian Populism Index, https://populismindex.com/ (last accessed 21 ${ }^{\text {st }}$ June 2019).

${ }^{2}$ https://www.wyzowl.com/video-social-media-2019/

${ }^{3}$ https://www.statista.com/statistics/568802/forecast-of-facebook-user-numbers-in-italy/

${ }^{4}$ https://www.statista.com/statistics/568845/forecast-of-facebook-user-numbers-in-the-spain/

${ }^{5}$ https://www.statista.com/statistics/568740/forecast-of-facebook-user-numbers-in-austria/

${ }^{6}$ See the well-known Manifesto Project dataset: https://manifesto-project.wzb.eu/

${ }^{7}$ https://www.lavoce.info/archives/54161/rischi-di-un-governo-bipolare/

${ }^{8}$ There are few missing cases concerning some variables when the LIWC software did not detect any word belonging to the categories included in the numerator or denominator of our index. Additionally, the category Personal is not available in the Spanish LIWC dictionary.

${ }^{9}$ This option was suggested by the Hausman test (except when analyzing Personal and Social). Using fixed effects (Table A13, Online Appendix) or a fractional logit does not alter our findings. The results hold even when including basic control variables, such as the type of video (interview on news media, advertisement, institutional speech or propaganda speech) or the intensity of the speech (rate of words). The findings are substantively similar to a simple mean comparison t-test.

${ }^{10}$ The full models are reported in the Online Appendix (Table A12, A14 and A15).

${ }^{11}$ While it is not possible to evaluate language complexity using standard measures based on the length of the sentences (since any punctuation is lost with the audio transcription), we rely on the rate of complex words composed of more than six letters under the idea that the length of the words reflects their complexity.

${ }^{12}$ https://www.bbc.com/news/world-europe-49287219

${ }^{13}$ https://www.bbc.com/news/world-europe-48335316

${ }^{14}$ https://www.ft.com/content/346cc922-ce69-11e9-99a4-b5ded7a7fe3f

${ }^{15}$ https://www.euronews.com/2019/09/04/podemos-insist-on-formal-coalition-as-price-for-saving-sanchez

${ }^{16}$ Strache became leader of the FPö in 2005, after a party split promoted by Jörg Haider, whose new party replaced the FPö as junior partner of the ruling coalition. 